\title{
Sanal Kaytarma ve İş Performansı İlişkisi: Kuşaklar Teorisi Yaklaşımı* (The Relationship between Cyber-Loafing and Job Performance: Generations Theory Perspective)
}

\author{
Erhan KUZNEK ${ }^{(D)}$ a Berrin GÜZEL (iDb \\ aAydın Adnan Menderes Üniversitesi, Sosyal Bilimler Enstitüsü, Aydın, Türkiye. erhankuznek@gmail.com \\ bAydın Adnan Menderes Üniversitesi, Turizm Fakültesi, Aydın, Türkiye. berringuzel@hotmail.com
}

\begin{tabular}{|c|c|}
\hline MAKALE BİLGİSİ & ÖZET \\
\hline Anahtar Kelimeler: & $\begin{array}{l}\text { Amaç - Araştırma çalışanların sanal kaytarma aktivite türlerinin belirlenmesi, bu aktivitelerin çalışan } \\
\text { performansına olan etkileri ile kuşaklara göre farklılıklarını tespit etme amacını taşımaktadır. }\end{array}$ \\
\hline $\begin{array}{l}\text { Kuşaklar teorisi } \\
\text { Sanal kaytarma } \\
\text { X kuşağ1 } \\
\text { Y kuşağ1 } \\
\text { Çalışan performansı. }\end{array}$ & $\begin{array}{l}\text { Yöntem - Araştırmada sanal kaytarma aktivitelerini ölçmek amaciyla Blanchard ve Henle (2008)'nin } 17 \\
\text { maddelik ölçeği kullanılmıştır. Çalışan performansını ölçmeye yönelik kullanılan ölçek ise Kirkman ve } \\
\text { Rosen (1999) tarafından geliştirilmiştir. Kirkman ve Rosen (1999) çalışan performansını; üretkenlik } \\
\text { (productivity), proaktiflik (proactivity) ve müşteri hizmetleri (customer service) olmak üzere üç boyutta } \\
\text { değerlendirmiştir. Sanal kaytarmanın üretkenlik karşıtı bir sapma davranışı olması (Lim, 2002: 677; } \\
\text { Blanchard ve Henle, 2008: 1070; Bortolani ve Favretto; 2009: 2925) nedeniyle sadece üretkenlik } \\
\text { (productivity) boyutu ölçeği kullanılmıştır. Araştırma İzmir ilinde yer alan yiyecek içecek işletmeleri } \\
\text { çalışanlarını kapsamaktadır. Veri toplamada anket tekniği kullanılarak toplam } 300 \text { adet anket katılımcılara } \\
\text { dağıtılmış, } 250 \text { kullanılabilir veri ile analizler gerçekleştirilmiştir. }\end{array}$ \\
\hline $\begin{array}{l}\text { Makale Kategorisi: } \\
\text { Araştırma Makalesi }\end{array}$ & $\begin{array}{l}\text { Bulgular - Araştırma sonucuna göre sanal kaytarmanın dört farklı boyutu bulunmaktadır. Bu boyutlar } \\
\text { zaman geçirme, gündem takibi, spor ve bahis ve sosyal paylaşım olarak adlandırılmıştır. Sanal } \\
\text { kaytarmanın zaman geçirme boyutunun çalışan performansını negatif yönde etkilediği ancak diğer } \\
\text { boyutlar ile anlamlı bir ilişkisinin olmadığı tespit edilmiştir. Ayrıca sanal kaytarmanın gündem takibi ve } \\
\text { sosyal paylaşım boyutlarında kuşaklara göre farklılık göstermektedir. Ayrıca çalı̧̧an performansının da } \\
\text { kuşaklara göre fark gösterdiğine ve bebek patlaması kuşağının en yüksek çalışan performansına sahip } \\
\text { olduğu tespit edilmiştir. }\end{array}$ \\
\hline & $\begin{array}{l}\text { Tartışma - Sanal kaytarma literatürde olduğu halinden farklı şekilde dört faktör olarak saptanmıştır. Elde } \\
\text { edilen boyutlar kuşaklardan farklı şekilde etkilenmektedir. Her kuşağın internet ile teknolojik araçlar ile } \\
\text { ilişki düzeylerinin birbirinden farklı olması, bunun nedenlerinden biridir. Kuşaklar iş performansları } \\
\text { yönünde de farklılaşmaktadır. Bu anlamda nasıl yetiştirildikleri veya nelere sahip olup/olmadıkları gibi } \\
\text { kuşakların yaşamış olduğu geçmiş deneyimler iş hayatlarındaki performanslarına da yansımaktadır. }\end{array}$ \\
\hline
\end{tabular}

\section{ARTICLE INFO}

\section{Keywords:}

Generation theory

Cyberloafing

Gen X

Gen $Y$

Job performance

Received 2 September 2019

Revised 27 November 2019

Accepted 1 December 2019

\section{ABSTRACT}

Purpose - This study aims to determine the forms of cyberloafing activities on employees along with the effects on their job performances according to generational differences.

Design/methodology/approach - In the study, cyberloafing activities were measured using Blanchard and Henle (2008)'s scale consist of 17 items. The employee performance is measured by the scale developed by Kirkman and Rosen (1999). Their scale had three dimensions, named as productivity, proactivity and customer service. As cyberloafing is considered as a deviant behavior against productivity, only productivity dimension is used. 300 questionnaires were given to food \& beverage employees in Izmir, however only 250 of them were analyzed.

Findings: As a result, exploratory factor analysis found that cyberloafing has four different dimensions. These dimensions were named as "recreational activities, checking updates, sports \& betting and social media". One of the cyberloafing dimensions which is called recreational activities were negatively related

*Bu çalışma Aydın Adnan Menderes Üniversitesi Sosyal Bilimler Enstitüsü Gastronomi ve Mutfak Sanatları bölümünde hazırlanmış olan aynı başlıklı tezden üretilmiştir.

\section{Önerilen Atıf/Suggested Citation}

Kuznek, E., Güzel, B. (2019) Sanal Kaytarma ve İş Performansı İlişkisi: Kuşaklar Teorisi Yaklaşımı, İşletme Araştırmaları Dergisi, 11 (4), 2729 2746. 
Article Classification:

Research Article with job performance. However, there was no significant relation between the other dimensions of cyberloafing and the job performance. Also, it is found that cyberloafing differs from generation to generation on recreational activities and social media dimensions. Besides, job performance also differs from generation to generation and it is found that baby boomers had the highest job performance rather than generation $\mathrm{X}$ and generation $\mathrm{Y}$.

Discussion - Cyber-loafing was found to have four factors different than the literature. Generations affect the dimensions obtained differently. The different levels of the relationship between the internet and technological tools of each generation is considered as one of the reasons for this interaction. Generations also differ in job performance. In this sense, past experiences of generations, such as how they are raised or what they have or not, are reflected in their job performance.

\section{GİRiş}

İnsanların ve işletmelerin yaşamında teknoloji konusundaki gelişmeler önemli etkilere yol açmıştır (Lim, 2002: 675; Hills ve Argyle, 2003: 59; Baş, 2017: 262). İşletmeler küresel rekabet koşullarında başarılı olabilmek adına amaç ve hedeflerini gerçekleştirebilmek, müşterilerine doğru ve hızlı hizmet verebilmek için zamanı iyi bir şekilde kullanmak zorundadır (Fındıklı, 2016: 35). Dolayısıyla internet erişimi; işletmelerde maliyetleri düşürme, iletişim kolaylığı sağlama, ürün ve servislerin tanıtım verimliliğini arttırma gibi konularda işletmelerin zaman tasarrufu yapmasına katkı sağlamaktadır (Anandarajan vd., 2004: 62). Ancak yine de internet erişimi, insanlarda daha fazla dikkat dağınıklığına neden olması gibi bir takım olumsuz sonuçlar da doğurtabilmektedir (Hartijasti ve Fathonah, 2014: 2). Günümüzde kolay şekilde erişilen ve giderek yaygınlaşan internet erişimi, insanların sadece özel hayatlarında kullandığı bir araç olmaktan çıkarak özel hayatlarının iş ortamlarına girmesini sağlamıştır. İşyerinde mesai saatleri içerisinde işyerinin internet erişimini kullanarak kişisel amaçlı web-sitelere girmek ve e-posta alıp göndermek gibi iş dışı aktiviteler de sanal kaytarma olarak tanımlanmıştır (Lim, 2002: 677).

Sanal kaytarma aktiviteleri çoğunlukla üretkenlik karşıtı ve iş dışı sapkın bir davranış olarak tanımlanmaktadır (Lim, 2002: 677; Blanchard ve Henle, 2008: 1070). Sanal kaytarma işletmeler için boşa geçen bir zaman olarak kabul edilmektedir ki (Lim ve Teo, 2005: 1083), Amerika Birleşik Devletleri'nde yapılan çalışmaya göre iş dışı sapkın davranışlar arasında en fazla boşa zaman harcayan aktiviteler arasındadır (44,7\%) (Malachowski, 2005: 1). Buna karşın sanal kaytarma çalışanların yaratıcılık özelliklerini desteklemesi, bilgi düzeylerini arttırması ve iş streslerini azaltmaya da yardımcı olması nedeniyle olumlu olarak kabul edilebilir (Oravec, 2002: 63; Anandarajan ve Simmers, 2004: 22; Blanchard ve Henle, 2008: 1080; Tan ve Demir, 2018: 52).

Sanal kaytarmaya yönelik önceki çalışmalarda bir takım sosyal ve demografik özelliklerin bu davranışı etkilediği saptanmıştır (Baş, 2017: 268; Vitak vd., 2011: 1756; Kaplan ve Çetinkaya, 2014: 31). Örneğin yaş değişkenine göre gençler yaşlılara göre daha fazla internet kullanmaktadır (Hills ve Argyle, 2003: 63). Aynı dönemlerde yaşayan, ortak özelliklere sahip bireylerin oluşturduğu grup olarak tanımlanan kuşaklar teorisinin sanal kaytarma davranışlarında bulunulmasında etkilidir (Hartijasti ve Fathonah, 2014: 11; Hartijasti ve Fathonah, 2015: 50; Amarat vd., 2017: 98). Zira Y kuşağındaki kişilerin en belirgin özelliklerinden biri olarak kabul edilen teknoloji tutkusu ile 7/24 internet erişiminde olmayı tercih etmesi (Gurlaş, 2016: 10; Özdemir, 2017: 46; Karahasan, 2018: 26; Kurtoğlu vd., 2016: 420), sanal kaytarma davranışlarını ciddi şekilde arttırmaktadır (Amarat vd., 2017). Bu bulgulardan hareketle mevcut çalışma çalışanlarının sanal kaytarma aktivite türlerinin belirlenmesi, bu aktivitelerin çalışan performansına olan etkileri ile kuşaklara ve cinsiyet durumuna göre farklılıklarını belirmeyi amaçlamaktadır. Bu sayede işletmelerde daha yaygın şekilde istihdam edilen $\mathrm{Y}$ kuşağı ile yeni giren $\mathrm{Z}$ kuşağının sanal kaytarma olarak tanımlanan davranışa eğilimi belirlenecek ve işletmelerin de bu çalışanlara ne şekilde yaklaşması gerektiğine rehberlik edebilecektir.

\section{KAVRAMSAL ÇERÇEVE}

\subsection{Kuşaklar Yaklaşımı}

'Kuşak' kelimesi "yaklaşık olarak aynı yıllarda doğmuş, aynı çağın şartlarını; dolayısıyla birbirine benzer sıkıntıları, kaderleri paylaşmış ve benzer ödevlerle yükümlü olmuş kişilerin topluluğu" olarak tanımlanır (Türk Dil Kurumu, 2018). Sosyalbilim metotları kullanılarak; sistematik ve ayrıntılı bir yaklaşımla bu kavram için geliştirilen 20. yüzyıldaki ilk çalışma olduğu belirtilen (Jaeger, 1985: 278) kavram ile ilgili ilk bilimsel çalışma 
1927/1928 yılında yazılan ve 1952 yılında tekrar yayınlanan Alman sosyolog Karl Mannheim'ın 'The Problem of Generations' adlı makalesi ile başlar (Taylor, 2008: 4; Sarıkaya, 2018: 1; Yücel, 2018: 28). Mannheim (1952) "kuşak" kavramını, insanların yaşadıkları konum kimliği ile belirli ‘yaş gruplarını' kapsayan tarihsel ve sosyal bir süreci temsil ettiğini belirtir.

Mannheim (1952) kuşakların varlığını toplumlardaki beş temel özellik ile mümkün olabildiğini belirtir. Bunlar, (1) kültürel süreç sırasında yeni katılımcılar ortaya çıkar (doğum), (2) bu süreçteki eski katılımcılar devamlı kaybolur (ölüm), (3) herhangi bir kuşaktaki üyeler tarihsel bir sürecin geçici olarak sadece sınırlı bir bölümüne katılabilir, (4) bu yüzden birikmiş olan kültürel mirasın devamlı iletilmesi gerekir ve (5) kuşaktan kuşağa yapılan bu geçiş devamlı bir süreçtir.

Mannheim'ın kuşak teorisi sosyal, kültürel ve tarihsel olarak aynı dönemde doğan kişilerin, bulundukları kuşağın oluşum süresince aynı ekonomik, sosyal, siyasi ve tarihsel olayların etkisinde birbirlerine yakın deneyimlere, davranışlara ve düşünce sistemine sahip olmasına dayanır (Ercömart, 2018: 15). Dolayısıyla kuşaklar kavramı, insanların birbirlerine yakın tarihlerde dünyaya gelmiş olmasının yanı sıra; benzer zevkler, davranışlar ve deneyimleri de kapsayan o zaman diliminin özelliklerini yansitan toplumsal bir üründür (Zemke vd., 2013: 4). Bu anlamda birbirine yakın konum ve yaş gruplarındaki bireylerin yaşadıkları benzer olaylar sonucunda kendi kuşak özelliklerini oluşturduğu söylenebilir.

Kuşakları gruplara ayırarak sınıflandırmak, tarihsel süreç içerisinde toplumların yaşadı̆̆ farklı dönüm noktaları ve aşamalar nedeniyle araştırmacılar için tartışma konusu olmuştur (Aksu, 2018: 84). Bu nedenle literatürde birbirine yakın ancak farklı tarihlerde (Tablo 1) ve isimlerde kuşaklar sınıflandırılır. Örneğin 1940'ların başından öncesine kadar olan dönem Sessiz Kuşak, Gaziler, Gelenekselciler, Olgunlar; 2. Dünya Savaşı ile 1960'ların ortası Bebek Patlaması, Patlama Kuşağı; 1960-1980 arası X kuşağı, X'ler kuşağı, 13. Kuşak; 1980'ler ile 1990'ların sonu veya 2000'lerin başı ise Milenyum Kuşağı, Y Kuşağı, Bir Sonrakiler Kuşağı, Net Kuşağı, Ben Kuşağı ve Dijital Kuşak olarak isimlendirilir (Reeves ve Oh, 2008: 296; Ercömart, 2018: 24).

Tablo 1. Kronolojik Kuşaklar Sıralaması

\begin{tabular}{|c|c|c|c|c|}
\hline Kaynaklar & Sessiz Kuşak & $\begin{array}{c}\text { Bebek } \\
\text { Patlamasi } \\
\end{array}$ & X Kuşağ1 & Y Kuşağ1 \\
\hline Howe ve Strauss (2000) & $1925-1943$ & $1943-1960$ & 1961-1981 & $1982-2003$ \\
\hline Zemke vd. (2000) & 1922-1943 & $1943-1960$ & $1960-1980$ & 1980-1999 \\
\hline Washburn (2000) & $1926-1945$ & $1945-1964$ & $1965-1981$ & $1982-2003$ \\
\hline Lancaster ve Stillman (2002) & 1900-1945 & 1946-1964 & $1965-1980$ & 1981-1999 \\
\hline Martin ve Tulgan (2002) & $1925-1942$ & $1946-1960$ & $1965-1977$ & $1978-2000$ \\
\hline Appelbaum (2005) & - & $1943-1960$ & 1961-1981 & - \\
\hline Kyles (2005) & $1900-1945$ & 1946-1964 & $1965-1979$ & 1980-1999 \\
\hline Oblinger ve Oblinger (2005) & 1946 ve öncesi & $1947-1964$ & $1965-1980$ & 1981-1995 \\
\hline Crumpacker ve Crumpacker (2007) & $1929-1945$ & $1946-1964$ & $1965-1979$ & 1980-1999 \\
\hline Fleschner (2007) & $1925-1945$ & $1946-1964$ & $1965-1980$ & $1981-2000$ \\
\hline Lyons (2007) & 1945 ve öncesi & 1945-1964 & $1965-1979$ & 1980 ve sonrası \\
\hline Sessa (2007) & $1925-1945$ & 1946-1963 & 1964-1982 & 1983 ve sonrası \\
\hline Cennamo ve Gardner (2008) & - & 1946-1961 & $1962-1979$ & 1980 ve sonrasi \\
\hline Wong (2008) & - & $1945-1964$ & $1965-1981$ & $1982-2000$ \\
\hline Haeberle vd. (2009) & $1930-1944$ & $1945-1964$ & $1965-1979$ & 1989-1999 \\
\hline Trower (2009) & $1925-1945$ & 1946-1964 & $1965-1980$ & $1981-2000$ \\
\hline Lamm ve Meeks (2009) & - & $1943-1960$ & 1961-1980 & $1981-2000$ \\
\hline Twenge vd. (2010) & $1925-1945$ & 1946-1964 & $1965-1980$ & 1980-2000 \\
\hline Zhang ve Bonk (2010) & 1946 ve öncesi & 1946-1964 & $1965-1976$ & 1977-1994 \\
\hline Williams ve Page (2011) & $1930-1945$ & 1946-1964 & $1965-1976$ & 1977-1994 \\
\hline
\end{tabular}

Kaynak: Aka, 2017: 23 
Araştırmacılar kuşakların belirlenmesini baz alan doğum yılları arasında hem fikir olamasalar da çoğunluğun sessiz kuşak genel olarak 1945 yılı öncesinde doğanlardan; Bebek patlaması kuşağı 1945 ile 1964 yılı arasında doğanlardan; X kuşağı 1965 ile 1980 yılı arasında doğanlardan; Y kuşağ1 1981 ile 1999 yılı arasında doğanlardan; $\mathrm{Z}$ kuşağı için ise 2000 yılı ve sonrası doğanlardan oluştuğu söylenebilir.

\subsubsection{Bebek Patlaması (Baby Boomers) Kuşağı}

İkinci Dünya Savaşı sonrası doğum oranlarının artması nedeniyle (Gürbüz, 2015: 41) 1946-1964 yılları arasında (Özdemir, 2017: 34) doğanlara yönelik ‘Baby Boomer' ifadesi ilk kez 1977 yılında kullanılır (Karahasan, 2018: 25). Bu kuşak aynı zamanda ‘Ben Kuşağı' (Zemke vd., 2013: 24) ve 'Sandviç Kuşağı' (Kuran, 2018: 68) olarak da bilinir. Otoriteye saygı duyan, disiplinli, paylaşımcı ebeveyn olmaları ile sadece kendi geleceklerine odaklanmış olmaları nedeniyle 'Ben Kuşağı' (Aksu, 2018: 87); kendi çocukları ile anne ve babalarına beraber bakmış olmaları nedeniyle de 'Sandviç Kuşağı' olarak adlandırılır (Kuyucu, 2014: 57).

Bu kuşağın en belirgin özellikleri otoriteye bağlı, sadakat duyguları yüksek, duygusal, gerektiğinde teknolojiyi kullanabilen, kanaatkâr, gelenek ve göreneklerine sahip çıkan bir kuşak olmalarıdır (Arslan ve Staub, 2015: 6). İş hayatına büyük önem veren bu kuşak üyeleri; idealist ve optimist bir yapıya sahip olmakla beraber yetişkinlik yıllarında gösterdikleri para kazanma hırsları nedeniyle eleştirilir (Karahasan, 2018: 25). Gramofon, buzdolabı, radyo ve TV gibi teknolojik aletlerin olduğu bir dönem itibari ile yetiştikleri için teknoloji ile ilişkileri ortalama düzeydedir (Özdemir, 2017: 34). Ancak bu gelişen teknolojilere ve internet çağına ayak uyduramadıkları anlamına gelmemektedir (Kuran, 2018: 69).

\subsubsection{Kuşă̆ı}

1965-1979 yılları arasında doğanlar (Şalap, 2016: 33) ve matematikte bilinmeyenin sembolü olan X'den alan (Marshall, 1997: 397) 'X kuşağı' ifadesi ilk olarak 1950'li yıllarda fotoğrafçı Robert Capa, daha sonra da Douglas Coupland tarafindan yazılan "Generation X: Tales for an Accelerated Culture" isimli romanın 1991 yılında yayınlanmasından sonra yaygınlaşır (Karahasan, 2018: 25). Bu kuşaktakiler 1989 yılında Berlin Duvarı'nın yıkılması, AIDS'in ortaya çıkması, kişisel bilgisayarların ve internetin insanların yaşamlarına girmeye başlaması ve Vietnam Savaşı'nın son dönemlerini yaşar (Aka, 2017: 38). Yaşanan bu olaylar ve belirsizlikler ile baş etmek zorunda kalan X kuşağı; daha çok çalışmaya, kariyer yapmaya ve daha çok para kazanmaya odaklanarak gelecek kaygılarını azaltmaya çabalar (Altuntuğ, 2012: 206).

Bu dönemde ortaya çıkan teyp, çamaşır makinesi, fotoğraf makinesi, transistörlü radyo ve pikap gibi teknolojik cihazlar; X kuşağına teknolojik anlamda geçmiş ve gelecek arasında bir köprü niteliğindedir (Özdemir, 2017: 40). Ergenlik dönemlerinde kişisel bilgisayarlarla, gençlik çağlarında ise bilgi işlem teknolojilerinin yer aldığı bir iş hayatına adım attıkları için (Karahasan, 2018: 26) Baby Boomer'lara göre teknoloji kullanımı konusunda daha etkilidirler.

\subsubsection{Y Kuşă̆ı}

Bu kuşaktakiler 1980-1999 yılları arasında doğanlardır (Göçmen, 2018: 17). 'Y' kelimesi sürekli sorgulayan ve sorumluluklarını eleştiren yapıya sahip olan kişilerden oluşmasından dolayı İngilizce' de "Neden" anlamına gelen "Why" kelimesinden türemiştir (Aksu, 2018: 90). Bilgisayar, cep telefonu ve internet gibi teknolojilerin içinde doğmuş olması ve bu araçları çok iyi kullanıyor olmaları en belirgin özellikleridir (Özdemir, 2017: 45).

Kişisel bilgisayarlar, internet ve cep telefonları ile büyüyen $Y$ kuşağı; tüm bu araçları hayatlarına entegre ederek tam bir teknoloji tutkunudur (Öz, 2015: 11). Teknoloji tutkuları ve dönemlerinde yokluk görmemeleri dolayısı ile Y kuşağı, sabrı ve beklemeyi bilmeyen tüketim ruhuna sahiptir (Gurlaş, 2016: 9). Cep telefonları, dizüstü bilgisayarlar, akıllı telefonlar, tabletler vb. teknolojik ürünleri hayatlarının ayrılmaz bir parçası olarak gören $Y$ kuşağı, 7/24 internet erişiminde olmayı tercih eder (Özdemir, 2017: 54).

\subsection{4. İş Hayatında Kuşaklar}

Zemke vd. (2000) kuşakları iş hayatlarındaki tutumlarına göre de değerlendirir. Buna göre bebek patlaması (19461964) kuşağı hizmet odaklı, azimli, fazla çalışmaya istekli ve iyi bir takım oyuncusu olmasına karşın, bütçeyi 
düşünmeyen ve anlaşmazlıklardan rahatsız olan bir yapıya sahiptir. Ayrıca sonuç yerine süreçlere önem vermesi, geribildirimlere karşı hassas olması ile birlikte farklı görüşlere karşı yargılayıcı tutum sergilemesi en belirgin olumsuz iş tutumlarıdır. X kuşağ (1965-1979) iş hayatında kendine güvenen, resmi olmamaktan hoşlanan, şüpheci bir yapıya sahiptir. Ayrıca işi sadece iş olarak görmekte, otoriyete sıradan yaklaşmakta ve teknoloji konusunda da beceriklidir (Zemke vd., 2000: 98). Son olarak Y kuşağı (1980-1999) şirket kendilerine iyi davrandıkça şirkete bağlılık gösteren, dolayısıyla aynı şirkette çok uzun süre çalışmaya gönüllü olmayan, çok bilgili olmadıkları ve dikkatleri dağınık olmalarına rağmen kariyer basamaklarını hızla çıkmayı tercih eden, takdir edilmediklerinde motivasyonların kaybeden, bu anlamda yöneticilerden geri bildirim almalarının önemli olduğu bir kuşaktır. Ayrıca, piyasa koşullarının altında bir ücrete çalışmayı da tercih etmezler (Karahasan, 2018: 169). Narsizm boyutunda özgüven sahibi olmaları, özgürlüğüne düşkün ve sabırsız yapıları nedeniyle de yaptığı işlerden çabuk sikılırlar (Kurtoğlu vd., 2016: 420).

\subsection{Sanal Kaytarma}

Bilgisayar, tablet ve cep telefonu gibi internet erişimine açık olan teknolojik araçların iş yerlerinde aktif bir şekilde kullanılması, işletmenin amaçlarına ulaşmasında büyük bir rol oynar (Kaplan ve Çetinkaya, 2014: 26). Dolayısıyla işletmelerde internet kullanımı son yıllarda bir gerekliliktir (Pindek vd., 2018: 147). Nitekim bu araçlar çalışanların birbirleriyle olan iletişimlerini kolaylaştırarak, gereksiz iş yüklerinden kurtulmasını yardımcı olur (Örücü ve Yıldiz, 2014: 99).

Ancak internet erişimli araçların iş dışında kullanılması olumsuz sonuçlar ortaya çıkarır. Bu da sanal kaytarma davranışlarını oluşturur ki Lim (2002) bunu "mesai saatleri içerisinde işyerinin internet erişimini kullanarak kişisel amaçl web-sitelere girmek ve e-posta alıp göndermek gibi iş dışı aktiviteler" olarak tanımlar. Anandarajan ve Simmers (2004) kişisel web kullanımı (PWU- Personal Web Usage) ile ifade ettiği sanal kaytarmayı 'mesai saatleri içerisinde işletmenin herhangi bir kaynağını kullanarak o anki iş ve sorumlulukları dışında gönüllü olarak yaptıkları online web aktiviteler' olarak açıklar.

Literatürde 'cyberbludging' (sanal olarak sorumluluktan kaçış) (Mills vd., 2001), 'cyberslacking' (sanal tembellik) (Block, 2001; Vitak vd., 2011; O’Neill vd., 2014; Garrett ve Danziger, 2008; Lavoie ve Pychyl, 2001; Ugrin vd., 2008; İnce ve Gül, 2011; Mills vd., 2001), 'non-work related computing -NWRC' (iş ile ilgisi olmayan bilgisayar kullanımı) (Bock ve Ho, 2009), 'cyberdeviancy' (sanal sapkınlık) (Weatherbee, 2010), 'internet deviance' (internet sapkınlığı), 'problematic internet use' (problemli internet kullanimı), 'on-line loafing' (internet üzerinden kaytarma), 'internet dependency' (internet bağımlılı̆̆ı) (Ünal ve Tekdemir, 2015), 'Personal web usage -PWU' (kişisel web kullanımı) (Anandarajan ve Simmers, 2004; Kim ve Byrne, 2011) adları altında yer almaktadır.

Kavrama dair birçok farklı tanım vardır (Lim ve Teo, 2005; Blanchard ve Henle, 2008; Ugrin vd., 2008; Bortolani ve Favretto, 2009; Askew, 2009; Weatherbee, 2010; Vitak vd., 2011; Kim ve Byrne, 2011). Tüm tanımlamaların ortak noktası 'kişisel amaçla', 'mesai saatleri içerisinde' ve 'iş ile ilgisi olmayan' eylemlerin 'teknolojik aygitlar' ile yapılmasıdır. Ancak tanımlamalarda internet erişiminin ön planda tutulduğu halde internet erişimi olmayan bilgisayar, cep telefonu ve tablet vb. aygıtlarda kişisel zaman geçirme olarak adlandırılabilecek; oyun oynama, ekitap okuma vb. internet erişimi gerektirmeyen aktivitelerin mesai saatlerinde yapılmasının sanal kaytarma davranışı olup olmadığı tartışmalıdır. Bu anlamda sanal kaytarma mevcut çalışmada 'çalışanların mesai saatleri içerisinde bilişim cihazların kullanarak kişisel amaçlarla yaptıkları iş ile ilgisi olmayan aktiviteler' şeklinde yeniden tanımlanir.

Sanal kaytarmayı Lim (2002) tarama aktiviteleri (internet sitelerini ziyaret etme) ve e-posta aktiviteleri (e-posta alışverişi) olarak ayırır. Spor ile ilgili web sitelerini ziyaret etmek, yatırım ile ilgili web sitelerini ziyaret etmek, eğlence ile ilgili web sitelerini ziyaret etmek, genel haber sitelerini ziyaret etmek, iş ile alakası olmayan web siteleri ziyaret etmek, yetişkin odaklı web sitelerini ziyaret etmek ve online kişisel ürün alışverişi ile iş dışı içerik indirme tarama aktiviteleri; iş ile alakası olmayan e-posta gönderme, alma ve kontrol etme ise e-posta aktiviteleridir (Lim, 2002: 685). Anandarajan vd. (2004) için sanal kaytarma dört grupta incelenir. Online oyun oynama, müzik indirme ve yetişkin odaklı internet sitelerini ziyaret etmek gibi işletmeyi olumsuz etkileyen aktiviteler yıkıcı (disruptive) aktiviteler; amaçsızca internette gezinme, hafta sonu için eğlenceli/sosyal etkinler arama, hobi/ilgi alanlarını 
keşfetme ve satın almak istenilen ürünler hakkında bilgi toplamak gibi aktivitelere eğlence amaçh (recreational) aktiviteler; işletme hakkında haberleri aramak, eğitici/öğretici kurslar hakkında bilgi toplamak, mesleki birliklerin internet sayfalarını ziyaret etmek ve güncel etkinlikler hakkında bilgi edinmek 'kişisel öğrenme (personal learning)' ile sosyal ağlarda işletme hakkında görüşmek, hükümet sitelerine göz gezdirmek ve sosyal ağlarda diğer işletmeler hakkında bilgi edinmek gibi aktiviteler de 'belirsiz (ambiguous) aktiviteler'dir (Anandarajan vd., 2004: 72).

Mahatanankoon vd. (2004) ise sanal kaytarmayı satın alma ve kişisel ticari aktiviteler (kişisel işler yapmak, kişisel yatırım ve banka etkinliklerinde bulunmak, online kişisel alışveriş yapmak, kişisel seyahat ve eğlence etkinliklerinde bulunmak); bilgi arama ve görüntüleme (online haberleri okumak (spor, hava durumu vb.), kişisel ilgi alanları ile alakalı hizmet veya ürün araştırmak, eğlence ürünlerini ve hizmetlerini görüntülemek, kişisel hobileri araştırmak, işletme dışında iş aramak); kişilerarası iletişim (arkadaş veya aileye elektronik kart, çiçek, hediye vb. ürün yollamak, birden çok kişiye e-posta listesine veya haber gruplarına e-posta göndermek/iletmek, online seri ilanları kullanmak, Hotmail, Yahoo vb. kişisel web tabanlı e-posta kullanmak); interaktif eğlence ve zaman geçirme (online sohbetlere katılmak, iş ile alakası olmayan haber gruplarına katılmak, online müzayedelere katılmak, online oyun oynamak, herhangi bir amaca dayanmadan internette sörf yapmak); kişisel veri indirme (kişisel eğlence amaçlı video, ses, resim, metin indirmek/görüntülemek, kişisel kullanım amaçlı yazılım indirmek) olarak gruplandirır.

Mevcut çalışmada değerlendirilen Blanchard ve Henle (2008) ise sanal kaytarma aktivitelerini önemsiz (minor) ve ciddi (serious) olarak inceler. E-posta alışverişi, haber-finans sitelerini ziyaret etmek gibi önemsiz sanal kaytarma aktivitelerinde bulunan çalışanların, uygunsuz veya sapkın bir davranış içerisinde bulunduklarına inanmadığını; yetişkin odaklı internet sitelerini ziyaret etmek, sohbet uygulamalarını kullanmak gibi ciddi sanal kaytarma aktivitelerinde bulunan çalışanların ise yaptıklarının sapkın bir davranış olduğunu ve iş yerinde yapılmasının uygun olmadığının farkında olduklarını belirtir (Blanchard ve Henle, 2008: 1080). Bu anlamda önemsiz sanal kaytarma aktivitelerinde bulunan çalışanların zamanlarını, iş ve sorumlulukları için harcamaları yerine kişisel işlerle uğraşarak farkında olmadan işletmeyi olumsuz yönde etkiledikleri, ciddi sanal kaytarma aktivitelerinde bulunanların ise farkında oldukları halde işletmeyi olumsuz yönde etkiledikleri söylenebilir.

\subsubsection{Sanal Kaytarma Öncülleri}

Sanal kaytarmanın öncülleri konusunda çok az sayıda çalışma vardır ve net bilgi yoktur (Andreassen vd., 2014: 907). Kişiliğin sanal kaytarmaya neden olmasından ayrı olarak (Doorn, 2011: 13; Jia vd., 2013: 362) az sayıdaki çalışmalardan Koay (2017) sanal kaytarmanın altı öncülü olduğunu belirtir. 'Algılanan sonuçlar' çalışanların sanal kaytarma davranışlarında bulunmaları ile elde ettikleri olumlu ve olumsuz neticelerin değerlendirmesidir (Betts vd., 2014: 35). Buna göre çalışan kendisine yararlı fayda sağlaması durumunda sanal kaytarma davranışında bulunur. 'İstek', çalışanın sanal kaytarma davranışındaki en önemli etkendir. Eylemin zevk/heyecan vermesi veya ilginç olması, davranış eğilimini arttırır. Çalışanın etkileşimde olduğu sosyal gruplar için olumlu/olumsuz algılanması ise 'sosyal faktörler' olarak tanımlanır. Ortamın sanal kaytarma davranışına uygun olması veya ceza verilmesi durumu ise 'koşulları kolaylaştırma' ve medya kullanımının sürekli kullanımı ile 'alışkanlık' haline gelmesi sanal kaytarmayı belirler (Koay, 2017: 144).

Doorn (2011) örgütsel, görevsel ve kişisel etkenlerin sanal kaytarmayı etkilediğini belirtir. İşletmenin örgütsel politikalarının sanal kaytarma davranışındaki çalışanlara yönelik politikaları bu eğilimi kontrol altında tutmaya yardımcı olur. Ancak Jia vd. (2013) bu konudaki politikaların sanal kaytarma davranışını azalttığını belirtir. İşin taleplerinin az olması (Blanchard ve Henle, 2008: 1068), diğer bir ifadeyle yapacak işin fazla olmaması çalışanların daha fazla kaytarma eğilimi sergilemesine neden olur. Ayrıca iş ve özel yaşamın birbirine geçmesi durumunda da sanal kaytarma gerçekleşir. Kişi evde iş yapabildiği gibi, iş yerinde de özel yaşamına zaman ayırması mümkündür (Doorn, 2011: 58).

Bu çalışmalardan ayrı olarak örgütsel adaletin düşük düzeyde algılanması durumunda çalışanlar kendilerinde etkisizleştirme davranışında bulunur ve kaytarma eğilimi sergiler (Lim, 2002: 687). Diğer yandan iş tatmini ile sanal kaytarma arasındaki ilişkide içsel tatminin sağlanması sanal kaytarmayı azaltırken, dışsal tatmin sanal kaytarmayı arttırır (Çavuşoğlu ve Palamutçuoğlu, 2017: 440). Örgütsel bağlılık ile ilişkisinde ise iki kavram 
arasında sadece devam bağlılığı ile zayıf da olsa ilişkilidir ve buna göre devam bağlılığının artması, sanal kaytarmayı da arttırır (Yüceler vd., 2017: 796).

\subsubsection{Sanal Kaytarmanın Sonuçları}

Koay (2017) iş stresini sanal kaytarmanın tek sonucu olarak belirtir. Buna göre sanal kaytarmanın artması çalışanlarda iş stresini de arttırır. Ancak tezat şekilde Oravec (2002) sanal kaytarmanın eğlendirici ve rahatlatıcı özelliklerinin iş stresini azaltarak çalışanlar açısından olumlu bir etkiye sahip olduğunu belirtir. Doorn (2011) ise sanal kaytarmanın iş performansı, iş yükümlülükleri ve tükenmişliği etkilediğini belirtir. Üretkenlik karşıtı olarak tanımlanan (Lim, 2002: 677; Blanchard ve Henle, 2008: 1070) sanal kaytarmanın kimi çalışmalarda işletmelerde verimliliği azaltırken (Askew, 2012: 40; Fındıklı, 2016: 55), kimi çalışmalarda performansı arttırır (Blanchard ve Henle, 2008: 1080). İş yükümlülüğü konusunda ise Lim (2002) ayrımındaki tarama aktiviteleri iş yükümlülüğünü olumlu etkilerken, e-posta aktiviteleri tam tersi şekilde olumsuz etkiler.

\section{3. İş Performansı}

‘Örgütlerin amaçlarına ulaşmasına katkıda bulunan ve bireylerin yetkinlik seviyelerine göre ölçülebilen bireysel davranışlar bütünü' olarak tanımlanan (Campbell, 1990; akt. Rotundo, 2002: 5) iş performansı, örgütsel ve bireysel olmak üzere ikiye ayrılır. Örgütsel performans, çalışanların bireysel performansı ile birlikte örgütün türü, yönetim yapısı, bulunduğu çevre koşulları, amaç ve hedefleri gibi faktörlerden etkilenir (Özkan, 2017: 61). Dolayısıyla bireysel performans örgütlerin gösterdikleri toplam performansın temelini oluşturur. Bu anlamda, bir örgütün performansı ancak çalışanın performansı kadar iyidir (Benligiray, 2004; akt. Çöl, 2008: 39). Nitekim çalışan performansı, çalışanların sorumluluğunda oldukları ve yapmaları gereken iş ya da görevlerin başarı derecesini gösterir (Benligiray, 1999; akt. Akman, 2018: 78).

Örgütlerin başarılı bir şekilde yaşamlarına devam edebilmesi, gelişen ve değişen çevre koşullarına ayak uydurabilmesi ve diğer örgütler ile rekabet edebilmesi insan kaynağı performansının, verimli ve etkin bir şekilde yönetilmesi ile mümkündür (Fındıklı, 2016: 39). Dolayısıyla da iş performansı örgütler açısından hayati bir değer taşır.

\section{YÖNTEM}

\subsection{Araştırma Modeli}

Aynı dönemlerde yaşayan ve ortak özelliklere sahip bireylerin oluşturduğu gruplardan oluşan kuşaklar (Adıgüzel vd., 2014: 165) arasında farklı beklentiler, değer yargıları ve özellikler olması nedeniyle çalışma ortamında da çalışanlar arasında tutum ve davranışlarda farklılıklar mümkündür (Kayacan, 2016: 5). Bilgisayar, akıllı cep telefon, tablet vb. gibi teknolojik cihazlar ile yapılan sanal kaytarma faaliyetleri, beraberinde çalışanlarda belli bir teknolojik bilgi ve becerinin var olmasını gerektirir. Bu anlamda en yaşlı kuşak olarak ele alınan bebek patlaması kuşağının ortalama derecede (Özdemir, 2017: 35), orta yaş kuşağı olarak ele alınan X kuşağının iyi derecede ve en genç kuşak olarak ele alınan Y kuşağının da çok iyi derecede (Öz, 2015: 11) teknoloji bilgi ve becerilerinden bahsedilir. Bu düşünceden hareketle teknoloji tutkunu olarak gösterilen Y kuşağı (Öz, 2015: 11) üyesi çalışanların, bebek patlaması ve $X$ kuşağı üyesi çalışanlardan daha fazla sanal kaytarma faaliyetlerinde bulunabilir. Nitekim Hills ve Argyle (2003)'ın genç çalışanların yaşlı çalışanlara göre interneti daha fazla kullanması, Hartijasti ve Fathonah (2014)'ın Y kuşağının bebek patlaması ve X kuşağına göre daha fazla sanal kaytarma davranışlarında bulunduğunu belirtmesi bu ifadeyi destekler niteliktedir. Bu sonuçlardan hareketle;

\section{H1: Sanal kaytarma davranışı, kuşaklara göre farklılık gösterir.}

Her kuşak üyesinin; çocukluk, ergenlik ve yetişkinlik dönemlerinde tanık olduğu sosyal, ekonomik ve siyasi olaylar bireylerin davranış ve tutumlarına yansır (Solmaz, 2017: 86) ve farklı kuşakların bir arada olduğu iş hayatında kuşaklararası farklılıklar yaratır (Kayacan, 2016: 73). Örneğin; bebek patlaması kuşağı iş ve aile arasında denge kurmayı tercih ederken $X$ kuşağı, iş dışında aile ve arkadaşları ile geçirebileceği eşit zamana sahip olmayı talep eder. Y kuşağı ise iş hayatında esneklik konusunda ısrar ederek çalışmanın eğlenceli ve anlamlı olmasını savunur (Hessenius, 2009: 8). Bu özellikler ve farklılıklar da çalışanların performansını etkileyebilir. Nitekim 
işlerinde özerklik hisseden, işleri hakkında daha fazla bilgi sahibi olan, karar verme süreçlerinde aktif ve işini anlamlı bulan çalışanlar daha yüksek performans gösterir (Kirkman ve Rosen, 1999: 70). Bu düşünceden hareketle;

H2: Çalışan performansı, kuşaklara göre farklılık göstermektedir.

Sanal kaytarma davranışları çalışan performansını olumlu ve/veya olumsuz şekilde etkileyebilir (Anandarajan vd., 2004: 61; Blanchard ve Henle, 2008: 1068). Kontrollü ve yapıcı olan sanal kaytarma faaliyetleri, çalışanların yaratıcılığını arttırabilir ve yoğun iş temposunda verilen bir mola olarak stresi azaltabilir (Oravec, 2002: 63). Bu anlamda sanal kaytarma bilinçli uygulamalar ile desteklendiğinde (Anandarajan vd., 2004: 73); stresli ve yoğun bir ortamda hizmet veren işletmelerde çalışanların performanslarını arttırabilir.

Diğer yandan üretkenlik karşıtı bir davranış olarak görülen sanal kaytarma davranışlarının iyi yönetilemediği ve bu davranışın sürekli yaşandığı işletmelerde iş performansı olumsuz olarak etkilenir (Varoğlu ve Sığrı, 2017: 685). Çalışanların işlerini yapmak yerine sanal kaytarma faaliyetlerinde bulunması; işlerin gecikmesine ve diğer çalışanların iş yüklerinin artmasına da sebep olabilir (Baş, 2017: 262). Dolayısı ile çalışanın kendi performansını düşürmesi aynı zamanda diğer çalışma arkadaşlarının performansının da düşmesine yol açabilir. Buna göre;

\section{H3: Sanal kaytarma, çalışan performansını etkilemektedir.}

\subsection{Evren ve Örneklem}

Araştırmanın evrenini İzmir'de yer alan yiyecek içecek işletmeleri oluşturmaktadır. Araştırmada kullanılan veriler 2019 yılı Şubat ve Mart aylarında elde edilmiştir. Yiyecek içecek işletmesi çalışanlarına toplam 300 adet anket dağıtılmışsa da sadece 278 tanesinde geri dönüş yapılmıştır. Ancak kullanılamayan veriler nedeniyle 28 adet anket analizlere dahil edilememiştir. Sonuç olarak toplamda 250 adet anket değerlendirmeye alınmıştır. Değerlendirmeye alınabilen veri geri dönüş oranı ise yaklaşı \% 84 'tür.

\subsection{Veri Toplama Araçları}

Araştırmada anket tekniği ile veri toplanmıştır. Sanal kaytarma aktivitelerini ölçmek amacıyla Blanchard ve Henle (2008)'nin 17 maddelik ölçeği kullanılmıştır. Ölçeğin orjinalinde sanal kaytarmanın önemli (serious) ve önemsiz (minor) olarak iki boyuttur (Blanchard ve Henle, 2008: 1078). Bu ölçeğin güvenilirlik katsayısı ise önemli sanal kaytarma boyutunda $(\alpha=, 80)$, önemsiz sanal kaytarma boyutunda ise $(\alpha=, 86)$ olarak tespit edilmiştir. Mevcut çalışmada yapılan ön test sonucunda iki farklı ifade olan 'iş ile ilgisi olmayan e-posta alırım' ve 'iş ile ilgisi olmayan e-posta gönderirim' ifadeleri birleştirilerek tek bir madde halinde kullanılmıştır. Dolayısıyla mevcut çalışmada sanal kaytarma ölçeği 16 ifadeden oluşmaktadır. Çalışan performansını ölçmeye yönelik kullanılan ölçek ise Kirkman ve Rosen (1999) tarafından geliştirilmiştir. Kirkman ve Rosen (1999) çalışmasında çalışan performansını; üretkenlik (productivity), proaktiflik (proactivity) ve müşteri hizmetleri (customer service) olmak üzere üç boyutta değerlendirmiştir. Sanal kaytarmanın üretkenlik karşıtı bir sapma davranışı olması (Lim, 2002: 677; Blanchard ve Henle, 2008: 1070; Bortolani ve Favretto; 2009: 2925) nedeniyle mevcut çalışmanın konusu ve kapsamı gereği sadece üretkenlik (productivity) boyutu ölçeği kullanılmıştır. Orjinal çalışmada bu ölçeğin güvenilirlik katsayısı $(\alpha=, 91)$ olarak tespit edilmiştir. Uygulanan anketlerde beşli likert tipi ölçek kullanılarak ifadeler '1- Kesinlikle katılmıyorum, 2- Katılmiyorum, 3- Ne katılıyorum ne katılmıyorum, 4- Katılıyorum, 5Kesinlikle katıliyorum' şeklindedir.

Araştırmada kullanılan iki farklı ölçeğin yanı sıra katılımcıların cinsiyet, doğum tarihi ve internet ile geçirdikleri ortalama süre de yer almaktadır. Katılımcıların doğum tarihlerine verdikleri cevaplar yaş grupları yerine kuşak sınıflandırmasına göre 1946-1964 yılları arasında olanların bebek patlaması kuşağı, 1965-1979 yılları arasında doğanların X kuşağı, 1980-1999 yılları arasında doğanların ise Y kuşağı olarak ifade edilmiştir.

\section{BULGULAR}

\subsection{Demografik Özellikler}

Araştırmaya katılan çalışanların \%52,4'ünü erkekler; \%47,2'sini ise kadınlar oluşturmaktadır. 1980-1999 tarihleri arasında doğan bireylerin bulunduğu kuşak olarak kabul edilen Y kuşağı, katılımcıların \%90,8'ini oluşturarak araştırmada büyük rol oynar. Y kuşağını takiben; X kuşağı (1965-1979) katılımcıların \%8'ini, bebek patlaması 
E. Kuznek - B. Güzel 11/4 (2019) 2729-2746

kuşağı (1946-1964) ise katılımcıların sadece \%0,8'ini oluşturur. Bu durum, çalışmanın yapıldı̆̆ı yıl itibari ile bebek patlaması kuşağının en genç üyesinin 55 yaşında olduğu düşünüldüğünde özellikle yiyecek içecek sektörü gibi emek-yoğun bir sektörde normal karşılanabilir. Daha genç ve dinamik çalışanların bulunması, sektörün çalışma koşullarından kaynaklandığı düşünülebilir.

Tablo 2. Katılımcıların Demografik Özellikleri

\begin{tabular}{ccclcc}
\hline Cinsiyet & $\mathbf{n}$ & $\mathbf{\%}$ & Kuşak & $\mathbf{n}$ & $\mathbf{\%}$ \\
\hline Erkek & 131 & 52,4 & Y Kuşağı & 227 & 90,8 \\
Kadın & 118 & 47,2 & X Kuşağı & 20 & 8,0 \\
Kayıp Değer & 1 & \multirow{2}{*}{4} & Bebek Patlaması Kuşağı & 2 &, 8 \\
& & & Kayıp Değer & 1 &, 4 \\
\hline Toplam & $\mathbf{2 5 0}$ & $\mathbf{1 0 0}$ & Toplam & $\mathbf{2 5 0}$ & $\mathbf{1 0 0}$ \\
\hline
\end{tabular}

Y kuşağında bulunan çalışanların \%42,3 gibi en yüksek oranının sanal kaytarma aktiviteleriyle gün içerisinde toplam 1 ila 2 saat, \%37'sinin 1 saate kadar, \%17,6'sının 2 ila 3 saat arası, \%3,1'inin ise 3 saat ve üzeri toplam zaman geçirir. X kuşağında bulunan çalışanların \%60'lık oran ile büyük bölümünün 1 saate kadar, \%25'inin 1 ila 2 saat arası, \%10'unun 3 saat ve üzeri ve son olarak sadece \%5'inin 2 ila 3 saat arası vakit geçirir. Bebek patlaması kuşağında bulunan çalışanların ise toplam 1 saate kadar gün içerisinde sanal kaytarma aktiviteleri ile zaman geçirir (Tablo 3).

Tablo 3. Katılımcıların Kuşaklara Göre İnternette Zaman Geçirme Süreleri

\begin{tabular}{ccc}
\hline Kuşaklar & $\mathbf{n}$ & $\mathbf{\%}$ \\
\hline Y Kuşağı & $\mathbf{2 2 7}$ & $\mathbf{9 0 , 8}$ \\
1-2 Saat arası & 96 & 42,3 \\
1 Saate kadar & 84 & 37,0 \\
2-3 Saat arası & 40 & 17,6 \\
3 Saat ve üzeri & 7 & 3,1 \\
\hline X Kuşağ1 & $\mathbf{2 0}$ & $\mathbf{8 , 0}$ \\
1 Saate kadar & 12 & 60,0 \\
1-2 Saat arası & 5 & 25,0 \\
3 Saat ve üzeri & 2 & 10,0 \\
2-3 Saat arası & 1 & 5,0 \\
\hline Bebek Patlaması Kuşağı & $\mathbf{2}$ & $\mathbf{0 , 8}$ \\
1 Saate kadar & 2 & 100,0 \\
\hline Kayıp Değer & $\mathbf{1}$ & $\mathbf{0 , 4}$ \\
\hline Toplam & $\mathbf{2 5 0}$ & $\mathbf{1 0 0}$ \\
\hline
\end{tabular}

\subsection{Faktör Analizleri}

Faktör analizini Kleinbaum, Kupper ve Miller (1998) "birbirleriyle ilişkili çok sayıdaki değişkeni az sayıda, anlamlı ve birbirinden bağımsız faktörler halice getiren ve yaygın olarak kullanılan çok değişkenli istatistik tekniklerinden biri" olarak ifade eder (akt. Kalayc1, 2005: 321). Faktör analizi; korelasyon matrisi oluşturma, Bartlett testi ve Kaiser- MeyerOlkin testi yöntemleri ile değişkenlerin sayısını azaltmak ve sınıflandırmak amacıyla kullanılır. Güvenilirlik analizi ise bu testlerin veya ölçeklerin güvenilirliklerini ve özelliklerini değerlendirmek içindir (Kalayc1, 2005: 403). Bu bağlamda sanal kaytarma açımlayıcı faktör ve güvenilirlik analizi Tablo 4'tedir. 
E. Kuznek - B. Güzel 11/4 (2019) 2729-2746

Tablo 4. Sanal Kaytarma İfadeleri Açımlayıcı Faktör Ve Güvenilirlik Analizi

\begin{tabular}{|c|c|c|c|c|}
\hline İfadeler & $\begin{array}{l}\text { Faktör } \\
\text { Yükleri }\end{array}$ & Özdeğer & $\begin{array}{c}\text { Açılanan Toplam } \\
\text { Varyans } \\
\end{array}$ & $\begin{array}{c}\text { Cronbach's } \\
\text { Alpha }(\alpha)\end{array}$ \\
\hline 1. Faktör: "Zaman Geçirme" & & 6,348 & 25,833 & ,869 \\
\hline Blogları okurum & ,822 & & & \\
\hline Müzik indiririm & 772 & & & \\
\hline Online kişisel ilan sayfalarını kontrol ederim & 718 & & & \\
\hline Online kişisel alışveriş yaparım & 708 & & & \\
\hline Online müzayede sitelerini ziyaret ederim & 659 & & & \\
\hline Kişisel web sayfama bakarım &, 579 & & & \\
\hline Yetişkin odaklı web sitelerine bakarım &, 573 & & & \\
\hline 2. Faktör: "Gündem Takibi" & & 1,875 & 17,092 &, 813 \\
\hline Kişisel e-posta alırım/gönderirim & ,833 & & & \\
\hline Kişisel e-postamı kontrol ederim & ,740 & & & \\
\hline Genel haber sitelerini ziyaret ederim & ,720 & & & \\
\hline Banka veya finansla ilgili sitelere bakarım & 619 & & & \\
\hline 3. Faktör: "Spor ve Bahis" & & 1,269 & 12,172 &, 539 \\
\hline Bahis ve kumar sitelerinin ziyaret ederim & 836 & & & \\
\hline Sporla ilgili sitelere bakarım & 686 & & & \\
\hline 4. Faktör: "Sosyal Paylaşım" & & 1,172 & 11,551 &, 826 \\
\hline Sohbet uygulamalarını kullanırım & ,819 & & & \\
\hline Sosyal paylaşım sitelerini ziyaret ederim & 758 & & & \\
\hline \multirow[t]{3}{*}{ Toplam Varyans } & & & 66,648 & 894 \\
\hline & & \multicolumn{3}{|c|}{$\begin{array}{l}\text { Kaiser-Meyer-Olkin Örneklem Yeterliliği ,880 } \\
\text { Bartlett's Küresellik Testi Yaklaşık Kikare 1892,251 }\end{array}$} \\
\hline & & & Serbestl & $\begin{array}{lr}\text { erecesi } & 120 \\
\text { p değeri } & , 000\end{array}$ \\
\hline
\end{tabular}

Blanchard ve Henle (2008) çalışmasında iki boyutta incelenen sanal kaytarma aktiviteleri, mevcut çalışmada yapılan faktör analizi sonucunda aynı ifadeler kullanılarak dört farklı boyuta ulaşılmıştır. Bu ifadelerden 'borsa ve yatırımla ilgili siteleri ziyaret ederim' ifadesi yapılan analiz sonucu faktör yükünün 0,50'nin altında kalması nedeniyle (0,487) herhangi bir boyutta anlamlı olmadığ1 (Sharma, 1996: 116) görülerek elenmiştir. İnceleme sonucunda birinci faktörde yer alan 7 ifade içerikleri gereği 'Zaman Geçirme' olarak adlandırılmıştır. Bu faktörde yer alan ifadelerin faktör yükleri 0,822 ile 0,573 arasında değişmektedir. Dört ifadeden oluşan ikinci faktör, 'Gündem Takibi' olarak adlandırılmıştır. Bu ifadelerin faktör yükleri 0,833 ile 0,619 arasında değişmektedir. Üçüncü faktör 'Spor ve Bahis' olarak adlandırılmış olup iki ifadedir İfadelerden birinin faktör yükü 0,836 ve diğerinin ise 0,686 olarak görülmektedir. Son faktör 0,819 ve 0,758 faktör yüklerine sahip olan iki ifadeden meydana gelen 'Sosyal Paylaşım' olarak adlandırılmıştır.

Çalışan performansı faktör analizi ile güvenilirlik analizi sonuçlarında ise altı ifadeden oluşan kavram tek boyutludur ve güvenilirlik sayısı $\alpha=0,826^{\prime}$ dır. Bu ifadelerin faktör yükleri ise 0,773 ile 0,636 arasında değişmektedir (Tablo 5). 
E. Kuznek - B. Güzel 11/4 (2019) 2729-2746

Tablo 5. Çalışan Performansı İfadeleri Faktör ve Güvenilirlik Analizi

\begin{tabular}{|c|c|c|c|c|}
\hline İfadeler & $\begin{array}{l}\text { Faktör } \\
\text { Yükleri }\end{array}$ & Özdeğer & $\begin{array}{c}\text { Açılanan Toplam } \\
\text { Varyans }\end{array}$ & $\begin{array}{c}\text { Cronbach's } \\
\text { Alpha }(\alpha)\end{array}$ \\
\hline Çalışan Performansı & & 3,019 & 50,323 & 800 \\
\hline Karar verme süreçlerine aktif olarak katılırım & ,773 & & & \\
\hline Hedeflerime ulaşırım ve/veya aşarım & 743 & & & \\
\hline İşimde özerklik hissederim & 710 & & & \\
\hline İşim için gereken tüm bilgilere sahibim & ,705 & & & \\
\hline İşimi anlamlı bulurum & 681 & & & \\
\hline Görevlerimi zamanında bitiririm & ,636 & & & \\
\hline \multirow[t]{3}{*}{ Toplam Varyans } & & & 50,323 & ,800 \\
\hline & & $\begin{array}{r}\text { Kais } \\
\text { Bartlet }\end{array}$ & $\begin{array}{l}\text { r-Meyer-Olkin Örnekle } \\
\text { 's Küresellik Testi Yakl }\end{array}$ & $\begin{array}{l}\text { Yeterliliği ,838 } \\
\text { Kikare 391,929 }\end{array}$ \\
\hline & & & Serbestl & $\begin{array}{lr}\text { erecesi } & 15 \\
p \text { değeri } & , 000\end{array}$ \\
\hline
\end{tabular}

\subsection{Fark Testleri}

Kruskal-Wallis testi, sürekli değişkenlere sahip ikiden fazla grup için karşılaştırma yapmayı sağlar (Demirgil, 2005: 106). Bu bağlamda sanal kaytarma ve kuşaklar arasındaki farklılıkları tespit etmek amacıyla Kruskal-Wallis testi yapılmıştır (Tablo 6).

Tablo 6. Kuşaklararası Sanal Kaytarma Farkı

\begin{tabular}{|c|c|c|c|c|c|}
\hline Değişkenler & $\mathbf{n}$ & Art.Ort. & Ki-Kare & S.Sapma & $\mathrm{p}$ \\
\hline Zaman Geçirme & 250 & 2,4943 & 4,361 & 1,06313 &, 113 \\
\hline Bebek Patlaması & 2 & 160,25 & & & \\
\hline Y Kuşağ & 227 & 127,39 & & & \\
\hline X Kuşağ1 & 20 & 94,38 & & & \\
\hline Gündem Takibi & 250 & 2,8530 & 6,495 & 1,12526 &, $039^{*}$ \\
\hline Bebek Patlaması & 2 & 208,25 & & & \\
\hline Y Kuşağ1 & 227 & 126,96 & & & \\
\hline X Kuşağ1 & 20 & 94,43 & & & \\
\hline Spor ve Bahis & 250 & 2,0740 & 2,417 & 1,06304 & ,299 \\
\hline Bebek Patlaması & 2 & 129,50 & & & \\
\hline Y Kuşağ1 & 227 & 127,02 & & & \\
\hline X Kuşağ & 20 & 101,60 & & & \\
\hline Sosyal Paylaşım & 250 & 3,9780 & 10,966 & 1,17047 &, $004^{*}$ \\
\hline Y Kuşağ & 227 & 129,31 & & & \\
\hline X Kuşağ1 & 20 & 85,60 & & & \\
\hline Bebek Patlaması & 2 & 30,00 & & & \\
\hline${ }^{*} p \leq 0,05 d f 2$ & & & & & \\
\hline
\end{tabular}

H1 Sanal kaytarma davranışı, kuşaklara göre farklılık göstermektedir hipotezinde sanal kaytarmanın gündem takibi $(2,8530)$ ve sosyal paylaşım $(3,9780)$ boyutlarında anlamlı olduğu görülmektedir. Gündem takibi en fazla bebek patlaması kuşağı tarafından yapılmaktadır (208,25). En az gündem takibi ise X kuşağı tarafındadır $(94,43)$. Sanal 
kaytarmanın sosyal paylaşım boyutunu ise en fazla Y kuşağı $(129,31)$, en az ise bebek patlaması kuşağ1 $(30,00)$ gerçekleştirmektedir. Diğer yandan sanal kaytarmanın zaman geçirme $(2,4943)$ ile bahis ve spor $(2,0740)$ boyutlarında kuşaklararası herhangi anlamlı bir fark görülememektedir.

Çalışmada çalışan performansı kuşaktan kuşağa farklılık göstermektedir. Bu bağlamda H2 Çalışan performansı, kuşaklara göre farklılık göstermektedir hipotezinde en yüksek çalışan performansına bebek patlaması kuşağının sahip olduğu $(175,00)$, en düşük çalışan performansına ise Y kuşağının sahip olduğu $(121,58)$ görülmektedir. X kuşağ çalışan performansı ise iki kuşak arasındadır $(158,83)$.

Tablo 7. Kuşaklar arası Çalışan Performansı Farkı

\begin{tabular}{|c|c|c|c|c|c|}
\hline Değişkenler & $\mathbf{n}$ & Art.Ort. & Ki-Kare & S.Sapma & $\mathrm{p}$ \\
\hline Çalışan Performansı & 250 & 4,0300 & 5,932 & 63398 &, $050^{*}$ \\
\hline Bebek Patlaması & 2 & 175,00 & & & \\
\hline X Kuşağ1 & 20 & 158,83 & & & \\
\hline Y Kuşağ1 & 227 & 121,58 & & & \\
\hline${ }^{*} p \leq 0,05 d f 2$ & & & & & \\
\hline
\end{tabular}

İki değişken arasında anlamlı bir ilişkinin olup olmadığını, derecesini ve yönünü gösteren korelasyon analizi (Sungur, 2005: 115) mevcut çalışmada sanal kaytarma ile çalışan performansı arasındaki ilişkiyi belirlemek için yapılmıştır (Tablo 8).

Tablo 8. Sanal Kaytarma Boyutları ve Çalışan Performansı Korelasyon Analizi

\begin{tabular}{|c|c|c|c|c|c|c|}
\hline Değişken & Art.Ort. & S.Sapma & 1 & 2 & 3 & 4 \\
\hline 1. Zaman Geçirme & 2,4943 & 1,06313 & 1 & & & \\
\hline Gündem Takibi & 2,8530 & 1,12526 &, $570^{* *}$ & 1 & & \\
\hline Spor ve Bahis & 2,0740 & 1,06304 &, $338^{* *}$ & $370^{* *}$ & 1 & \\
\hline Sosyal Paylaşım & 3,9780 & 1,17047 &, $526^{* *}$ & $312^{* *}$ & $255^{* *}$ & 1 \\
\hline 5. Çalışan Performansı & 4,0300 & 63398 &,$- 148^{*}$ &,- 013 &, 003 &,- 117 \\
\hline
\end{tabular}

${ }^{* *} p \leq 0,01{ }^{*} p \leq 0,05 n=250$

Korelasyon analizi sonucunda çalışan performansı ile sanal kaytarmanın zaman geçirme faktörü arasında $(-, 148)$ negatif yönlü bir ilişki olduğu saptanmıştır. Bunun dışındaki diğer üç faktör ile çalışan performansı arasında anlamı bir ilişki bulunamamıştır.

Regresyon analizi, "bir bağımlı değişken ile bir bağımsız veya birden fazla bă̆ımsız değişken arasındaki ilişkilerin bir matematiksel eşitlik ile açıklanması sürecidir" (Küçüksille, 2005: 199). Sanal kaytarma faktörlerinin çalışan performansına yönelik regresyon analizi Tablo 9'dadır.

Tablo 9. Sanal Kaytarma Boyutlarının Çalışan Performansına Yönelik Regresyon Analizi

\begin{tabular}{llccccccc}
\hline Model & Değişkenler & B & S. Hata & $\boldsymbol{\beta}$ & $\boldsymbol{t}$ & $\boldsymbol{p}$ & $\boldsymbol{R}^{\mathbf{2}}$ & $\boldsymbol{R}^{\mathbf{2}}$ \\
\hline Sanal & (Sabit) & 4,228 &, 156 & & 27,017 &, 000 & & \\
Kaytarma & Zaman Geçirme &,- 110 &, 051 &,- 185 & $-2,154$ &, $032 *$ & & \\
& Gündem Takibi &, 053 &, 044 &, 095 & 1,206 &, 229 & & \\
& Spor ve Bahis &, 028 &, 041 &, 046 &, 673 &, 502 & & \\
& Sosyal Paylaşım &,- 033 &, 040 &,- 061 &,- 827 &, 409 & &, 018 \\
\hline
\end{tabular}

${ }^{*} p \leq 0,05 n=250$

Regresyon analizi sonucunda sanal kaytarmayı oluşturan dört faktörden, sadece zaman geçirme boyutunun çalışan performansını açıkladığı görülmektedir. Her ne kadar beklenen seviyeden oldukça düşük şekilde bulunsa da H3 Sanal kaytarma çalışan performansını etkilemektedir hipotezi desteklenmektedir. 
E. Kuznek - B. Güzel 11/4 (2019) 2729-2746

\section{SONUÇ VE TARTIŞMA}

Mevcut çalışma çalışanların sanal kaytarma aktivite türlerinin belirlenmesi, bu aktivitelerin çalışan performansına olan etkileri ile kuşaklara göre farklılıklarını tespit etmeye yöneliktir. Buna göre sanal kaytarma çalışan performansını etkiler ve sanal kaytarma davranışı kuşaklara göre farklılık gösterir.

Çalışmada, Blanchard ve Henle (2008)'in iki faktörlü sanal kaytarma modelinden (önemli ve önemsiz sanal kaytarma) farklı bir şekilde sanal kaytarma dört faktördür. Bu faktörler zaman geçirme, gündem takibi, spor ve bahis ve sosyal paylaşım olarak adlandırılmıştır. Elde edilen sonuçlarda zaman geçirme boyutu, blog okuma (Anandarajan vd., 2004; Mahatanankoon vd., 2004: 95), müzik indirme (Lim, 2002: 685; Anandarajan vd., 2004: 72), kişisel ilan sayfalarının kontrol edilmesi (Mahatanankoon vd., 2004: 95), online kişisel alışveriş (Lim, 2002: 685; Mahatanankoon vd., 2004: 95), online müzayede sitelerini ziyaret etme (Mahatanankoon vd., 2004: 95) ve yetişkin odaklı web sitelerine bakma (Lim, 2002: 685; Anandarajan vd., 2004: 72) ile; gündem takibi boyutu, kişisel e-posta gönderme/alma, e-posta kontrol etme, genel haber sitelerini ziyaret etme ve banka veya finansla ilgili sitelere bakma (Lim, 2002: 685; Mahatanankoon vd., 2004: 95) ile örtüşür. Spor ve bahis boyutu, spor ile ilgili siteler bakma (Lim, 2002: 685) ile sosyal paylaşım boyutu ise sohbet uygulamalarını kullanma ve sosyal paylaşım sitelerini ziyaret etme (Mahatanankoon vd., 2004: 95) ile benzerdir.

Sanal kaytarma davranışı sosyal paylaşım ve gündem takibi boyutlarında kuşaklara göre farklılık gösterir. Bebek patlaması kuşağı sanal kaytarmanın gündem takibi boyutunda en fazla aktif olduğu görülürken sosyal paylaşım boyutunda ise en az aktif kuşaktır. Çalışanların sanal kaytarma gündem takibi boyutundaki aktivitelerinde bulunmasının, mevcut çalışmanın yapıldığı tarih itibari ile seçim öncesi bir döneme denk gelmesi ile ülke gündeminin ekonomik ve siyasi olarak sürekli değişmesinden kaynaklandığı düşünülebilir. Öte yandan Y kuşağ1 her iki boyutta da $X$ kuşağından daha fazla sanal kaytarma aktivitelerinde bulunmaktadır. Nitekim Amarat vd. (2017) çalışmasında Y kuşağının X kuşağından daha fazla; ayrıca Hartijasti ve Fathonah (2014) ve Hartijasti ve Fathonah (2015) Y kuşağı çalışanlarının yoğun sanal kaytarma davranışlarında bulunduğu sonucuna ulaşması mevcut çalışmanın sonuçları ile benzerlik gösterir. Y kuşağının; bilgisayar ve hızlı iletişim araçları ile büyümüş olmaları, teknoloji tutkunu olmaları, 7/24 internet erişiminde olmayı tercih etmeleri, her türlü bilgiye internet aracılığı ile ulaşabilmeleri, özgürlüğüne düşkün ve sabırsız olmaları (Washburn, 2000: 54; Öz, 2015: 11; Gurlaş, 2016: 9; Özdemir, 2017: 54; Karahasan, 2018: 26; Kurtoğlu vd., 2016: 420) bu sonucu açılayabilir.

Çalışmanın sonuçlarından bir diğeri ise kuşak ile iş performansı arasında anlamlı bir fark bulunmasıdır. En yüksek çalışan performansına bebek patlaması kuşağı, en düşük çalışan performansına ise $Y$ kuşağının sahiptir. Bebek patlaması kuşağının iş hayatında; azimli, fazladan çalışmaya istekli, takım çalışmasına yatkın, disiplinli ve otoriteye bağlı (Aksu, 2018: 87; Arslan ve Staub, 2015: 6; Karahasan, 2018: 25; Zemke vd., 2000: 24) gibi özellikleri bu bulguyu destekleyebilir. Y kuşağının ise sabırsızlığı, dikkat dağınıklığı ve yaptıkları işin takdir edilmemesi nedeniyle heyecanlarını yitirmesi ve bazı işleri yapmaktan kaçınması gibi özellikleri (Karahasan, 2018: 168; Kurtoğlu vd., 2016: 420) etkili olabilir.

Kuşaklar ile sanal kaytarmanın zaman geçirme, spor ve bahis boyutlarının arasında anlamlı bir fark bulunmamıştır. Özellikle zaman geçirme gibi sanal kaytarma aktivitelerinin büyük bir bölümünü oluşturan boyutun kuşaklar ile arasında anlamlı bir fark bulunamamış olması şaşırtıcı niteliktedir. Ancak blog okuma, alışveriş sitelerini ziyaret etme gibi aktiviteler zaman alıcı ve işyerinde uzun süreli işten uzaklaşma sorunu yaratabilmektedir. Bu bağlamda Y kuşağında bulunan çalışanların büyük bölümünün bir ile iki saat arasında sanal kaytarma aktivitelerinde bulunmaktadır. Bebek patlaması kuşağı ile $X$ kuşağının büyük bölümleri ise gün içerisinde ortalama bir saate kadar sanal kaytarma aktiviteleri ile zaman geçirdikleri sonucuna ulaşılmıştır. Bu sonucu Y kuşağının teknoloji tutkuları ve 7/24 internet erişiminde olmayı tercih etmeleri (Gurlaş, 2016: 9; Özdemir, 2017: 54; Karahasan, 2018: 26; Kurtoğlu vd., 2016: 420) gibi özellikler etkileyebilir.

Son olarak sanal kaytarmayı oluşturan dört faktörden, sadece zaman geçirme faktörünün çalışan performansını etkilemektedir. Dolayısı ile çalışanların sanal kaytarma davranışlarında bulunmaları iş performanslarına 
sanılanın aksine oldukça düşük seviyede etkiler. Bu anlamda mevcut çalışma bulgusu Fındıklı (2016) çalışmasına benzerdir.

Çalışma sonuçları ile araştırma beraberinde bazı eleştirileri de getirmektedir. Örnekleme bakıldığında bebek patlaması, $X$ ve $Y$ kuşağı katılımcı sayılarının eşit veya ölçülü olarak dağılmadığı görülmektedir. Bu sayı her ne kadar iş hayatında $Y$ kuşağının büyük bir yeri olduğunu gösterse de katılımcıların neredeyse tamamının $Y$ kuşağından oluşması bir sınırlılık olarak görülebilir. Bu konuda bebek patlaması kuşağının yavaş yavaş iş hayatından çıkması ve Z kuşağının da iş hayatına yeni girmesi ile birlikte ilerleyen yıllarda çalışmanın yeniden değerlendirilmesi önerilir. Bir diğer konu ise çalışanlarının performansları anketteki ifadeler üzerinden kendi beyanları doğrultusunda ölçülmüştür. Bu bağlamda dışarıdan ölçülebilen, farklı bir performans değerlendirme yöntemine gidilmemiştir. Gelecek çalışmaların bu durumu ortadan kaldırabilmesi için farklı performans değerlendirme yöntemleri kullanması önerilir.

Sanal kaytarma genel olarak mesai saatleri içerisinde internet kullanımına odaklanır. Mesai saatlerinde müzik dinlemek, oyun oynamak ve e-kitap okumak gibi internet erişimi dışında da yapılabilen aktivitelerin sanal kaytarma aktivitesi olarak değerlendirilip değerlendirilmemesi ile sanal kaytarma aktivite sınırları belirsizliğini halen daha korumaktadır (Ünal ve Tekdemir, 2015: 98). Mevcut çalışmada nicel bir yaklaşım sergilenmiş, Blanchard ve Henle (2008) tarafından geliştirilen ve internet odaklı sanal kaytarma ölçeği test edilmiştir. Gelecek çalışmalar nitel bir yaklaşım sergileyerek bu sınırların üzerindeki belirsizliği, literatüre farklı sanal kaytarma aktiviteleri kazandırarak kaldırabileceği düşünülmektedir.

\section{KAYNAKLAR}

Adıgüzel, O., Batur, H. Z. ve Ekşili, N. (2014). Kuşakların Değişen Yüzü ve Y Kuşağı ile Ortaya Çıkan Yeni Çalışma Tarzı: Mobil Yakalılar. Süleyman Demirel Üniversitesi Sosyal Bilimler Enstitüsü Dergisi, 19, 165-182.

Aka, B. (2017). Kamu ve Özel Sektörde Çalışan Yöneticilerin Kuşak Farklllıkları ve Örgütsel Düzeyleri Arasındaki İlişkinin Incelenmesi: İzmir İlinde Bir Araştırma. Doktora Tezi, İzmir Kâtip Çelebi Üniversitesi Sosyal Bilimler Enstitüsü, İzmir.

Akman, A. (2018). Çatışma Yönetimi, İş Tatmini, Kariyer Tatmini, İş Performansı ve İşten Ayrılma Niyeti Üzerine Bir Araştırma. Doktora Tezi, Osmaniye Korkut Ata Üniversitesi Sosyal Bilimler Enstitüsü, Osmaniye.

Aksu, B. Ç. (2018). Kuşaklar Açısından Motivasyon Araçlarının ve Kariyer Çapalarının Karşılaştırılması ve Bir Araştırma. Yüksek Lisans Tezi, İstanbul Üniversitesi Sosyal Bilimler Enstitüsü, İstanbul.

Altuntuğ, N. (2012). Kuşaktan Kuşağa Tüketim Olgusu ve Geleceğin Tüketici Profili. Organizasyon ve Yönetim Bilimleri Dergisi, 4(1), 203-212.

Amarat, M., Durmuş, A., Şahin, H. ve Güleryüz, M. (2017). Kuşaklar Arasındaki Sanal Kaytarma Davranışlarının Belirlenmesi. 1.International 11. Health and Hospital Administration Conference Kitabı, Trabzon, 93-99.

Anandarajan, M., Devine, P., ve Simmers, C. A. (2004). A Multidimensional Sealing Approach to Personal Web Usage in the Workplace. In Personal Web Usage in the Workplace: A Guide to Effective Human Resources Management (ss. 61-79). IGI Global.

Anandarajan, M., ve Simmers, C. A. (2004). Constructive and Dysfunctional Personal Web Usage in the Workplace: Mapping Employee Attitudes. In Personal Web Usage in the Workplace: A Guide to Effective Human Resources Management (ss. 1-27). IGI Global.

Andreassen, C. S., Torsheim, T. ve Pallesen, S. (2014). Predictors of use of social network sites at work-a specific type of cyberloafing. Journal of Computer-Mediated Communication, 19(4), 906-921.

Arslan, A., ve Staub, S. (2015). Kuşak Teorisi ve Içgirişimcilik Üzerine Bir Araştırma. Kafkas Üniversitesi İktisadi ve İdari Bilimler Fakültesi Dergisi, 6(11), 1-24. 
E. Kuznek - B. Güzel 11/4 (2019) 2729-2746

Askew, K. (2009). Testing the Plausibility of a Series of Causal Minor Cyberloafing Models. Master Dissertation, University of South Florida College of Arts and Sciences, USA.

Askew, K. L. (2012). The Relationship between Cyberloafing and Task Performance and An Examination of the Theory of Planned Behavior as a Model of Cyberloafing. Doctoral Dissertation, University of South Florida College of Arts and Sciences, USA.

Baş, M. (2017). Cyberloafing Tendency in Applications of Students who have Tourism and Culinary Training. Journal of Strategic Research in Social Science, 3(4), 261-270.

Betts, T. K., Setterstrom, A. J., Pearson, J. M., ve Totty, S. (2014). Explaining Cyberloafing through a Theoretical Integration of Theory of Interpersonal Behavior and Theory of Organizational Justice. Journal of Organizational and End User Computing, 26(4), 23-42.

Blanchard, A. L., ve Henle, C. A. (2008). Correlates of Different Forms of Cyberloafing: The Role of Norms and External Locus of Control. Computers in Human Behavior, 24(3), 1067-1084.

Block, W. (2001). Cyberslacking, Business Ethics and Managerial Economics. Journal of Business Ethics, 33(3), 225231.

Bock, G. W., ve Ho, S. L. (2009). Non-Work Related Computing (NWRC). Communications of the ACM, 52(4), 124.

Bortolani, E., ve Favretto, G. (2009). Organizational Aspects of Cyberloafing. In Encyclopedia of Information Science and Technology, Second Edition (pp. 2923-2928). IGI Global.

Çavuşoğlu, S., ve Palamutçuoğlu, B. T. (2017). İş Tatmininin Sanal Kaytarma Üzerindeki Etkisi. Mehmet Akif Ersoy Üniversitesi Sosyal Bilimler Enstitüsü Dergisi, 9(19), 430-444.

Çöl, G. (2008). Algılanan Güçlendirmenin Işgören Performansı Üzerine Etkileri. Doğuş Üniversitesi Dergisi, 9(1), 35-46.

Demirgil, H. (2005). Parametrik Olmayan (non-parametric) Hipotez Testleri., Ş. Kalaycı (Editör), SPSS Uygulamalı Çok Değişkenli Istatistik Teknikleri içinde (85-112) (Birinci Baskı). Ankara. Asil Yayın Dağıtım.

Doorn, O. N. V. (2011). Cyberloafing: A Multi-Dimensional Construct Placed in a Theoretical Framework. Master Thesis. Department Industrial Engineering and Innovation Sciences Eindhoven University of Technology, Netherlands.

Ercömart, Ç. (2018). Kuşak Teorileri Bağlamında Endüstri Ürünleri Tasarımı Eğitiminin Değişim Dinamikleri ve Değerlendirilmesi. Yüksek Lisans Tezi, Gazi Üniversitesi Fen Bilimleri Enstitüsü, Ankara.

Fındıklı, M. A. (2016). Sanal Kaytarma ve Iş Performansı İlişkisi: Sağlık ve Tekstil Sektörü Çalışanlarının Karşılaştırılması. International Journal of Social Inquiry, 9(1), 33-62.

Garrett, R. K., ve Danziger, J. N. (2008). On Cyberslacking: Workplace Status and Personal Internet Use at Work. Cyber Psychology \& Behavior, 11(3), 287-292.

Göçmen, S. (2018). X ve Y Kuşaklarının Yönetim Alg̨ları: Kurumsal Iş̧letmelerde Nitel bir Araştırma. Yüksek Lisans Tezi, Bahçeşehir Üniversitesi Sosyal Bilimler Enstitüsü, İstanbul.

Gürbüz, S. (2015). Kuşak Farklılıkları: Mit mi, Gerçek mi? İş ve İnsan Dergisi, 2(1), 39-57.

Gurlaş, M. S. (2016). Jenerasyon Teorisine göre X ve Y Kuşakların Örgütsel Băğlllk, İş Tatmini ve İşten Ayrılma Niyeti Farklılılarının İncelenmesi; Kamuda Vergi Dairesi Çalışanları Üzerine Bir Araştırma. Yüksek Lisans Tezi, Nişantaşı Üniversitesi Sosyal Bilimler Enstitüsü, İstanbul.

Hartijasti, Y., ve Fathonah, N. (2014). Cyberloafing across Generation X and Y in Indonesia. Journal of Information Technology Applications \& Management, 21(1), 1-16. 
E. Kuznek - B. Güzel 11/4 (2019) 2729-2746

Hartijasti, Y. ve Fathonah, N. (2015). Motivation of Cyberloafers in the Workplace Across Generations in Indonesia. International Journal of Cyber Society and Education, 8(1), 49-58.

Hessenius, B. (2009). Involving Youth in the Arts Project: Phase II-Focus Groups on Next Generation Leadership. William and Flora Hewlett Foundation. USA.

Hills, P. ve Argyle, M. (2003). Uses of the Internet and Their Relationships with Individual Differences in Personality. Computers in Human Behavior, 19(1), 59-70.

İnce, M., ve Gül, H. (2011). The Relation of Cyber Slacking Behaviors with Various Organizational Outputs: Example of Karamanoğlu Mehmetbey University. European Journal of Scientific Research, 52(4), 507-527.

Jaeger, H. (1985). Generations in History: Reflections on a Controversial Concept. History and Theory, 24(3), 273292.

Jia, H., Jia, R., ve Karau, S. (2013). Cyberloafing and Personality: The Impact of the Big Five Traits and Workplace Situational Factors. Journal of Leadership \& Organizational Studies, 20(3), 358-365.

Kalaycı, Ş. (2005). Faktör analizi., Ş. Kalaycı (Editör), SPSS Uygulamalı Çok Değiş̧kenli Istatistik Teknikleri içinde (321331) (Birinci Baskı). Ankara. Asil Yayın Dağıtım.

Kaplan, M., ve Çetinkaya, A. Ş. (2014). Sanal Kaytarma ve Demografik Özellikler Açısından Farklılıklar: Otel İşletmelerinde Bir Araştırma. Anatolia: Turizm Araştırmaları Dergisi, 25(1), 26.

Karahasan, F. (2018). Açlın Gençler Geliyor. İstanbul, Doğan Egmont Yayıncılık.

Kayacan, E. (2016). X ve Y Kuşaklarının Motivasyon Kaynakları: Bankacılık Sektörü Üzerine Bir Alan Araştırması. Doktora Tezi, İstanbul Üniversitesi Sosyal Bilimler Enstitüsü, İstanbul.

Kim, S. J., ve Byrne, S. (2011). Conceptualizing Personal Web Usage in Work Contexts: A Preliminary Framework. Computers in Human Behavior, 27(6), 2271-2283.

Kirkman, B. L. ve Rosen, B. (1999). Beyond Self-Management: Antecedents and Consequences of Team Empowerment. Academy of Management journal, 42(1), 58-74.

Koay, K. Y. (2017). Antecedents and Consequences of Cyberloafing among ICT Employees in MSC Status Companies. Master Thesis, Multimedia University Faculty of Management, Malaysia.

Kuran, E. (2018). Telgraftan Tablete Türkiye'nin Beş Kuşağına Bakış. Destek Yayınları, İstanbul.

Kurtoğlu, R., Sönmez, A. T. ve Temiz, S. (2016). Tüketicilerin Yaş Kuşaklarına Göre WOM Hakkındaki Değerlendirmeleri. Eurasian Business \& Economics Journal, Vol. s.2, 416-430.

Kuyucu, M. (2014). Y Kuşağı ve Facebook: Y Kuşağının Facebook Kullanım Alışkanlıkları Üzerine Bir İnceleme. Elektronik Sosyal Bilimler Dergisi, 13(49), 55-83.

Lavoie, J. A. A., ve Pychyl, T. A. (2001). Cyberslacking and the Procrastination Superhighway: A Web-Based Survey of Online Procrastination, Attitudes, and Emotion. Social Science Computer Review, 19(4), 431-444.

Lim, V. K. G. (2002). The IT way of Loafing on the Job: Cyberloafing, Neutralizing and Organizational Justice. Journal of Organizational Behavior, 23(5), 675-694.

Lim, V. K. G., ve Teo, T. S. H. (2005). Prevalence, Perceived Seriousness, Justification and Regulation of Cyberloafing in Singapore. Information \& Management, 42(8), 1081-1093.

Mahatanankoon, P., Anandarajan, M., ve Igbaria, M. (2004). Development of a Measure of Personal Web Usage in the Workplace. CyberPsychology \& Behavior, 7(1), 93-104.

Malachowski, D. (2005). Wasted Time at Work Costing Companies Billions. San Francisco Chronicle, 11. 
Mannheim, K. (1952). The Problem of Generations., P. Kecskemeti (Editor), In Karl Mannheim: Essays (276-322). Routledge.

Marshall, G. S. (1997). Theory and Generation X. Journal of Public Administration Education, 3(3), 397-403.

Mills, J. E., Hu, B., Beldona, S., ve Clay, J. (2001). Cyberslacking! A Liability Issue for Wired Workplaces. Cornell Hotel and Restaurant Administration Quarterly, 42(5), 34-47.

O’Neill, T. A., Hambley, L. A., ve Bercovich, A. (2014). Prediction of Cyberslacking When Employees are Working Away From the Office. Computers in Human Behavior, 34, 291-298.

Oravec, J. A. (2002). Constructive Approaches to Internet Recreation in the Workplace. Communications of the ACM, 45(1), 60-63.

Örücü, E., ve Yildiz, H. (2014). İşyerinde Kişisel İnternet ve Teknoloji Kullanımı: Sanal Kaytarma. Ege Akademik Bakış (Ege Academic Review), 14(1), 99-114.

Öz, Ü. (2015). XYZ Kuşaklarının Özellikleri ve Y Kuşağının Örgütsel Bă̆lılık Düzeyi Analizi. Yüksek Lisans Tezi, Atılım Üniversitesi Sosyal Bilimler Enstitüsü, Ankara.

Özdemir, Ş. (2017). Kuşaklar Teorisine göre Türkiye'deki Gençlerin Medya Kullanım Alışkanlıkları ve İstanbul Örneği. Yüksek Lisans Tezi, Marmara Üniversitesi Sosyal Bilimler Enstitüsü, İstanbul.

Özkan, C. (2017). İşin Anlamlılığının Iş Performansı ve Sapma Davranışına Etkisi: Mersin Ilinde Yapilan Bir Araştirma. Doktora Tezi, Mersin Üniversitesi Sosyal Bilimler Enstitüsü, Mersin.

Pindek, S., Krajcevska, A., ve Spector, P. E. (2018). Cyberloafing as a Coping Mechanism: Dealing with Workplace Boredom. Computers in Human Behavior, 86, 147-152.

Reeves, T. C., ve Oh, E. (2008). Generational Differences. Handbook of Research on Educational Communications and Technology, 3, 295-303.

Rotundo, M. (2002). Defining and Measuring Individual Level Job Performance: A Review and Integration. Doctoral Dissertation, Joseph L. Rotman School of Management University of Toronto, Canada.

Şalap, K. O. (2018). Çalışma Yaşamında Kuşaklar: Kuşakların Iş ve Özel Yaşam Dengesine Ilişkin Yaklaşımları. Yüksek Lisans Tezi, İstanbul Üniversitesi Sosyal Bilimler Enstitüsü, İstanbul.

Sarıkaya, O. (2018). X ve Y Kuşaklarının Karar Verme Stilleri ve Risk Alma Eğilimleri Açısından Karşılaştırmalı Analizi. Yüksek Lisans Tezi, Akdeniz Üniversitesi Sosyal Bilimler Enstitüsü, Antalya.

Sharma, S. (1996). Applied Multivariate Techniques. USA. John Wiley \& Sons, Inc.

Solmaz, B. (2017). Kuşaklar ve Çalışma Değerleri: X ve Y Kuşă̆ı Akademik Personelinin Çalışma Değerlerine Bakışı. Doktora Tezi, İstanbul Üniversitesi Sosyal Bilimler Enstitüsü, İstanbul.

Sungur, O. (2005). Korelasyon Analizi., Ş. Kalaycı (Editör), SPSS Uygulamalı Çok Değişkenli Istatistik Teknikleri içinde (115-127) (Birinci Baskı). Ankara. Asil Yayın Dağıtım.

Tan, M., ve Demir, M. (2018). İşgörenlerin Kişilik Özelliklerinin Sanal Kaytarma Davranışı Üzerindeki Etkisi. International Journal of Social Sciences and Education Research, 4(1), 49-60.

Taylor, J. C. (2008). Whither March the Cohorts: The Validity of Generation Theory as a Determinant of the Sociocultural Values of Canadian Forces Personnel. Toronto: Canadian Forces College National Security Studies Program.

Türk Dil Kurumu. (2018). Kuşak. $17 \quad$ Ocak $2019 \quad$ tarihinde www.tdk.gov.tr/index.php?option=com_gts\&kelime=KUŞAK adresinden alınmıştır.

Ugrin, J. C., ve Michael Pearson, J. (2013). The Effects of Sanctions and Stigmas on Cyberloafing. Computers in Human Behavior, 29(3), 812-820. 
E. Kuznek - B. Güzel 11/4 (2019) 2729-2746

Ünal, Ö. F., ve Tekdemir, S. (2015). Sanal Kaytarma: Bir Kamu Kurumunda Ampirik Bir Araştırma. Süleyman Demirel Üniversitesi İktisadi ve İdari Bilimler Fakültesi Dergisi, 20(2), 95-118.

Varoğlu, D. ve Sığrı, Ü. (2017). Örgütsel Davranışın Karanlık Yüzü: İşyerinde Üretkenlik Karşıtı Davranışlar., Ü. Sığrı ve S. Gürbüz. (Editörler), Örgütsel Davranış içinde (674-704) (Güncellenmiş Dördüncü Baskı). İstanbul. Beta Yayınları.

Vitak, J., Crouse, J., ve LaRose, R. (2011). Personal Internet Use at Work: Understanding Cyberslacking. Computers in Human Behavior, 27(5), 1751-1759.

Washburn, E. R. (2000). Are You Ready for Generation X? (Changing World View). Physician Executive, 26(1), 5158.

Weatherbee, T. G. (2010). Counterproductive Use of Technology at Work: Information \& Communications Technologies and Cyberdeviancy. Human Resource Management Review, 20(1), 35-44.

Yücel-Güngör, M. (2018). Kuşakların Sosyal Medya Kullanımının Yiyecek Içecek Işletmesi Tercihleri Üzerine Etkisi. Doktora Tezi, Aydın Adnan Menderes Üniversitesi Sosyal Bilimler Enstitüsü, Aydın.

Yüceler, A., Kaya, Ş. D. ve Özen, M. Y. Örgütsel Bağl1lık ile Sanal Kaytarma Ilişkisinin Incelenmesi. 25. Ulusal Yönetim ve Organizasyon Kongresi Bildiriler Kitabı. Ankara. 794-797

Zemke, R., Raines, C., ve Filipczak, B. (2000). Generations at Work: Managing the Clash of Veterans, Boomers, Xers, and Nexters in Your Workplace. First Edition. Amacom. USA.

Zemke, R., Raines, C., ve Filipczak, B. (2013). Generations at Work: Managing the Clash of Boomers, Gen Xers, and Gen Yers in the Workplace. Second Edition. Amacom. USA. 